\title{
Citrinin Derivatives from the Soil Filamentous Fungus Penicillium sp. H9318
}

\author{
Guangmin Yao, ${ }^{a, d}$ Fred Musoke Sebisubi, ${ }^{b, e}$ Lok Yung Christopher Voo, ${ }^{c}$ Coy Choke Ho, ${ }^{c}$ \\ Ghee Teng Tan ${ }^{b}$ and Leng Chee Chang*,a,b
}

\author{
${ }^{a}$ Department of Chemistry and Biochemistry, College of Science and Engineering, \\ University of Minnesota Duluth, 1039 University Drive, Duluth, MN 55812, USA \\ ${ }^{b}$ Department of Pharmaceutical Sciences, College of Pharmacy, University of Hawaii Hilo, \\ 34 Rainbow Drive, Hilo, HI 96720, USA \\ ${ }^{c}$ Biotechnology Program, School of Science and Technology, University Malaysia Sabah, \\ 88999 Kota Kinabalu, Sabah, Malaysia \\ ${ }^{d}$ Hubei Key Laboratory of Natural Medicinal Chemistry and Resources Evaluation, School of \\ Pharmacy, Tongji Medical College, Huazhong University of Science and Technology, \\ 13 Hangkong Road, Wuhan 430030, P. R. China \\ ${ }^{e}$ Division of Pharmaceutical Services, Ministry of Health, \\ PO Box 7272 Kampala, Uganda
}

\begin{abstract}
A investigação do extrato orgânico produzido na fermentação microbiológica de Penicillium sp. H9318 conduziu ao isolamento de um novo alcaloide isoquinolínico, o composto (5S)-3,4,5,7-tetrametil-5,8-di-hidróxi-6(5H)-isoquinolinona (1), juntamente com quatro outros conhecidos compostos derivados da citrinina (2-5). Uma atividade inibitória significativa no ensaio da inibição da formação dos halos (HFI), foi exibida pela citrinina (2), semelhante àquela observada pelo Streptomyces $85 \mathrm{E}$, enquanto os compostos 1, 3, 4 e 5 não mostraram atividade inibitória com respeito ao ensaio HFI quando testados com $20 \mu \mathrm{g} /$ disco. Em relação ao ensaio de citotoxicidade, a citrinina (2) demonstrou uma atividade inibitória mais fraca quando comparada as linhagens de células cancerosas MCF-7 ( $\left.\mathrm{IC}_{50} 71,93 \mu \mathrm{mol} \mathrm{L}-1\right), \operatorname{LNCaP}\left(\mathrm{IC}_{50} 77,92 \mu \mathrm{mol} \mathrm{L}-1\right)$, LU-1 $\left(147,85 \mu \mathrm{mol} \mathrm{L}{ }^{-1}\right)$ e $\mathrm{KB}\left(\mathrm{IC}_{50} 65,93 \mu \mathrm{mol} \mathrm{L}{ }^{-1}\right)$.

Investigation of a microbial fermentation organic extract of Penicillium sp. H9318 led to the isolation of a new isoquinolinone alkaloid, $(5 S)$-3,4,5,7-tetramethyl-5,8-dihydroxyl-6(5H)isoquinolinone (1), along with four known citrinin derivatives (2-5). Citrinin (2) exhibited significant inhibitory activity against Streptomyces $85 \mathrm{E}$ in the hyphae formation inhibition (HFI) assay, while compounds $\mathbf{1}, \mathbf{3}-\mathbf{5}$ were not active when tested at $20 \mu \mathrm{g} /$ disk in the HFI assay. Citrinin (2) further demonstrated a weak inhibitory activity against MCF-7 ( $\left.\mathrm{IC}_{50} 71.93 \mu \mathrm{mol} \mathrm{L}{ }^{-1}\right), \mathrm{LNCaP}$ $\left(\mathrm{IC}_{50} 77.92 \mu \mathrm{mol} \mathrm{L}^{-1}\right), \mathrm{LU}-1\left(147.85 \mu \mathrm{mol} \mathrm{L}^{-1}\right)$ and $\mathrm{KB}\left(\mathrm{IC}_{50} 65.93 \mu \mathrm{mol} \mathrm{L}^{-1}\right)$ cell lines, respectively, in the cytotoxicity assay.
\end{abstract}

Keywords: Streptomyces 85E, isoquinolinone alkaloid, citrinin, Penicillium sp. H9318, kinase inhibitor

\section{Introduction}

The phosphorylation of proteins on serine/threonine and tyrosine residues by protein kinases is one of the major regulatory mechanisms in biological processes including apoptosis, cell proliferation, cell differentiation,

*e-mail: lengchee@hawaii.edu and metabolism. Deregulated phosphorylation associated with these pathways can result from genetic alterations acquired early in tumorigenesis, and are often the cause of cancer. In this regard, protein kinases have emerged as promising inhibitory targets in cancer treatment. ${ }^{1,2}$ Aerial hyphae formation of Streptomyces sp. requires protein kinase activity. It has been shown that a variety of kinase inhibitors block this process. ${ }^{3,4}$ 
During the course of our search for novel protein kinase inhibitors from natural resources, ${ }^{5-10}$ an acetonesoluble extract of the fungus Penicillium sp. H9318 showed inhibitory activity towards both mammalian protein phosphatase 1 (PP1) and protein phosphatase 2A (PP2A) in an in vitro phosphatase assay. ${ }^{5}$ The $n-\mathrm{BuOH}-$ soluble extract exhibited inhibitory activity in the hyphae formation inhibition (HFI) assay with Streptomyces $85 \mathrm{E}$ giving a $20 \mathrm{~mm}$ clear zone of inhibition at $80 \mu \mathrm{g} / \mathrm{disk}$. These preliminary results encouraged us to investigate the fungus Penicillium sp. H9318 for the discovery of novel protein kinase inhibitors. A bioassay-directed fractionation of the organic extract has resulted in the isolation of a novel isoquinolinone alkaloid 3,4,5,7-tetramethyl-5,8dihydroxyl-6(5H)-isoquinolinone, namely, isoquinocitrinin A (1), and four known compounds, citrinin (2), penicitrone A (3), penicitrinols A (4) and B (5). Herein, we report the isolation, structure elucidation, and biological activities of compounds 1-5.

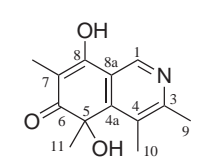

1

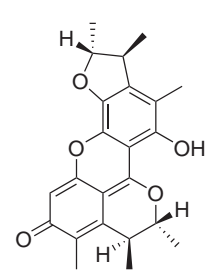

3

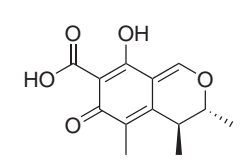

2

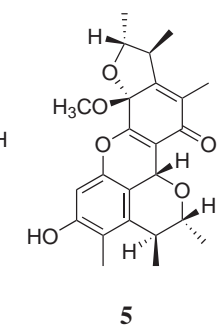

5

\section{Results and Discussion}

The fungus Penicillium sp. H9318 was isolated from a soil sample collected at a heath forest in Maliau Basin, Sabah, Malaysia. The $\mathrm{CHCl}_{3}$-soluble partition (26.6 g) of the $n$-BuOH extract of fermented Penicillium sp. H9318 significantly inhibited the growth of hyphae formation in Streptomyces $85 \mathrm{E}$ at a concentration of $80 \mu \mathrm{g} /$ disk. A bioassay-guided isolation of the active fractions by repeated Sephadex LH-20 and silica gel MPLC afforded compounds 1-5. The known compounds 2-5 were identified as citrinin (2), ${ }^{11-13}$ penicitrone A (3) (also known as dicitrinin A), ${ }^{14}$ penicitrinol A (4) ${ }^{15}$ and penicitrinol B (5), ${ }^{16}$ respectively, by spectroscopic analysis and comparison with literature data.

Compound 1 was obtained as a colorless oil, with the molecular formula $\mathrm{C}_{13} \mathrm{H}_{15} \mathrm{NO}_{3}$ determined from the ${ }^{1} \mathrm{H}$ and ${ }^{13} \mathrm{C}$ NMR data (Table 1) and HRESIMS $(\mathrm{m} / \mathrm{z} 234.11248$
$[\mathrm{M}+\mathrm{H}]^{+}$, calc. 234.11247), indicating seven degrees of unsaturation. The UV absorption bands at $\lambda_{\max } 249,269$, $293,307,330 \mathrm{~nm}$ indicated the presence of an extended conjugated chromophore. The ${ }^{1} \mathrm{H}$ NMR spectrum of 1 (Table 1) displayed signals of an aromatic proton at $\delta_{\mathrm{H}} 8.85(1 \mathrm{H}, \mathrm{s}, \mathrm{H}-1)$, three aromatic methyls at $\delta_{\mathrm{H}} 2.66$ $(3 \mathrm{H}, \mathrm{s}, \mathrm{H}-10), 2.57$ (3H, s, H-9) 1.89 (3H, s, H-12); and a tertiary methyl at $\delta_{\mathrm{H}} 1.62(3 \mathrm{H}, \mathrm{s}, \mathrm{H}-11)$. The ${ }^{13} \mathrm{C}$ NMR and DEPT spectrum exhibited 13 carbon signals, including one carbonyl $\left(\delta_{\mathrm{C}} 188.5\right)$, one $\mathrm{sp}^{2}$ methine $\left(\delta_{\mathrm{C}} 143.9\right)$, six sp ${ }^{2}$ quaternary carbons $\left(\delta_{\mathrm{C}} 178.8,161.1,152.4,131.9,126.0\right.$ and 108.5), one oxygen-bearing $\mathrm{sp}^{3}$ quaternary carbon $\left(\delta_{\mathrm{C}} 73.6\right)$, and four methyls $\left(\delta_{\mathrm{C}} 29.3,22.9,16.8\right.$ and 8.3). One carbonyl and four double bonds from the ${ }^{13} \mathrm{C}$ NMR spectra accounted for five degrees of unsaturation, thus the remaining two degrees of unsaturation requires the presence of two rings in $\mathbf{1}$.

Table 1. NMR spectroscopic data for compounds $\mathbf{1}$ in $\mathrm{CD}_{3} \mathrm{OD}(500 \mathrm{MHz})$

\begin{tabular}{lccc}
\hline Position & $\delta_{\mathrm{H}}$, multiplicity & $\delta_{\mathrm{C}}$ & $\mathrm{HMBC}(\mathrm{H} \rightarrow \mathrm{C})$ \\
\hline 1 & $8.85, \mathrm{~s}$ & 143.9 & $\mathrm{C} 3, \mathrm{C} 4 \mathrm{a}, \mathrm{C} 8, \mathrm{C} 8 \mathrm{a}$ \\
3 & & 161.1 & \\
4 & & 131.9 & \\
$4^{\mathrm{a}}$ & & 152.4 & \\
5 & & 73.6 & \\
6 & & $188.5^{a}$ & \\
7 & & 108.5 & \\
8 & & $178.8^{a}$ & \\
$8^{\mathrm{a}}$ & & 126.0 & \\
9 & $2.57, \mathrm{~s}$ & 22.9 & $\mathrm{C} 3, \mathrm{C} 4$ \\
10 & $2.66, \mathrm{~s}$ & 16.8 & $\mathrm{C} 3, \mathrm{C} 4, \mathrm{C} 4 \mathrm{a}$ \\
11 & $1.62, \mathrm{~s}$ & 29.3 & $\mathrm{C} 4 \mathrm{a}, \mathrm{C} 5, \mathrm{C} 6$ \\
12 & $1.89, \mathrm{~s}$ & 8.3 & $\mathrm{C} 6, \mathrm{C} 7, \mathrm{C} 8$ \\
\hline${ }^{a}{ }^{\mathrm{W}}$ Weakly observed in ${ }^{13} \mathrm{C} \mathrm{NMR}$ spectrum, assigned by $\mathrm{HMBC}$
\end{tabular}

${ }^{a}$ Weakly observed in ${ }^{13} \mathrm{C}$ NMR spectrum, assigned by HMBC.

Comparison of its ${ }^{1} \mathrm{H}$ and ${ }^{13} \mathrm{C}$ NMR data (Table 1) with those of citrinin (2) showed that these compounds differ in the presence of C-3 and C-4 sp ${ }^{2}$ quaternary carbons $\left(\delta_{\mathrm{C}} 161.1\right.$ and 131.9) in $\mathbf{1}$ rather than the $\mathrm{C}-3$ and $\mathrm{C}-4 \mathrm{sp}^{3}$ methines $\left(\delta_{\mathrm{C}} 82.0\right.$ and 33.4) in $\mathbf{2}$. The ${ }^{1} \mathrm{H}$ and ${ }^{13} \mathrm{C}$ assignments of $\mathbf{1}$ were confirmed by analysis of the HMBC spectrum (Figure 1). Long-range correlations were observed between the signal of $\mathrm{H}-1\left(\delta_{\mathrm{H}} 8.85\right)$ and C-3 $\left(\delta_{\mathrm{C}} 161.1\right)$; between $\mathrm{CH}_{3}-9\left(\delta_{\mathrm{H}} 2.57\right)$ and $\mathrm{C}-3\left(\delta_{\mathrm{C}} 161.1\right), \mathrm{C}-4\left(\delta_{\mathrm{C}} 131.9\right)$; as well as between $\mathrm{CH}_{3}-10$ $\left(\delta_{\mathrm{H}} 2.66\right)$ with C-3 $\left(\delta_{\mathrm{C}} 161.1\right), \mathrm{C}-4\left(\delta_{\mathrm{C}} 131.9\right)$ and C-4a $\left(\delta_{\mathrm{C}} 152.4\right)$. Another major difference in the ${ }^{13} \mathrm{C}$ NMR spectrum of compounds $\mathbf{1}$ and $\mathbf{2}$ was that C-12 was changed from a carbonyl group $\left(\delta_{\mathrm{C}} 174.0\right)$ in $\mathbf{2}$ into a methyl group $\left(\delta_{\mathrm{C}} 8.3\right)$ in 1. Also, $\mathrm{HMBC}$ correlations of $\mathbf{1}$ from $\mathrm{CH}_{3}-12\left(\delta_{\mathrm{H}} 1.89, \mathrm{~s}\right)$ 


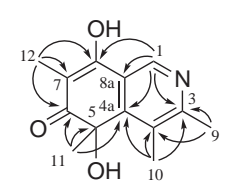

Figure 1. Key HMBC correlations $(\mathrm{H} \rightarrow \mathrm{C})$ for compound $\mathbf{1}$.

to $\mathrm{C}-6\left(\delta_{\mathrm{C}} 188.5\right), \mathrm{C}-7\left(\delta_{\mathrm{C}} 108.5\right)$, and C-8 $\left(\delta_{\mathrm{C}} 178.8\right)$ revealed that the methyl $\mathrm{C}-12$ was located at $\mathrm{C}-7$. Furthermore, the cross peaks of the methyl $\mathrm{CH}_{3}-11\left(\delta_{\mathrm{H}} 1.62, \mathrm{~s}\right)$ with $\mathrm{C}-4 \mathrm{a}\left(\delta_{\mathrm{C}} 152.4\right)$, C-5 $\left(\delta_{\mathrm{C}} 73.6\right)$ and C-6 $\left(\delta_{\mathrm{C}} 188.5\right)$, along with a NOESY correlation observed between $\mathrm{CH}_{3}-11$ and $\mathrm{CH}_{3}-10$ confirmed that the methyl $\mathrm{C}-11$ was connected to an oxygen bearing $\mathrm{sp}^{3}$ quaternary carbon at C-5. In consideration of the molecular formula and the ${ }^{13} \mathrm{C}$ NMR chemical shift, C-5 $\left(\delta_{\mathrm{C}} 73.6\right)$ and C-8 $\left(\delta_{\mathrm{C}} 178.8\right)$ were substituted by hydroxyl groups, and a N atom must be assigned to position 2. In spite of our utmost efforts, the absolute configuration at C-5 of compound $\mathbf{1}$ has yet to be ascertained. Therefore, compound $\mathbf{1}$ was elucidated as 3,4,5,7-tetramethyl-5,8-dihydroxyl-6(5H)-isoquinolinone and named isoquinocitrinin $\mathrm{A}$.

Several similar novel isoquinoline alkaloids have been reported from the genus of Penicillium, ${ }^{17}$ Aspergillus, ${ }^{18}$ Streptomyces ${ }^{19,20}$ and Chaetomium. ${ }^{21}$ Most isoquinoline alkaloids discovered from plants exhibit complicated structures, which were mainly synthesized from tyrosine, whereas most isoquinolines from lichens, fungi, and sponges show simple skeletons and are probably biosynthesized via mixed pathways. ${ }^{21}$

Compound 1 possesses a carbon skeleton similar to citrinin (2), and it is possibly biosynthesized via mixed routes. The proposed biosynthesis of compound $\mathbf{1}$ proceeds via an enzyme-bonded poly- $\beta$-ketone chain ${ }^{22}$ and the amino acid formation is accomplished by an aminotransferase (Scheme 1).

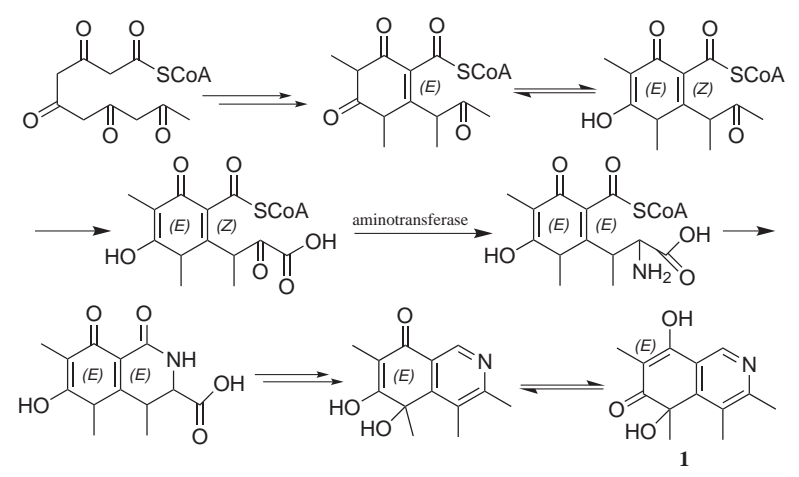

Scheme 1. Proposed biogenesis pathway of compound $\mathbf{1}$.

Citrinin (2) was first isolated from P. citrium in 1931 and it has been isolated from ten or more species of Penicillium and Aspergillus. Compounds 3-5 are known citrinin dimer derivatives. Until now, more than ten citrinin dimers have been discovered from natural resources. ${ }^{14,16}$ This is the first report of an isoquinolinone alkaloid from the genus Penicillium possessing a carbon skeleton similar to that of citrinin.

Compounds 1-5 were evaluated for their inhibitory activities against Streptomyces $85 \mathrm{E}$ in the hyphae formation inhibition assay, according to an established protocol. ${ }^{4}$ Compound 2 exhibited significant inhibitory activity and gave a $21 \mathrm{~mm}$ clear zone of inhibition (ZOI) at $80 \mu \mathrm{g} /$ disk, $17 \mathrm{~mm}$ clear ZOI at $40 \mu \mathrm{g} /$ disk, $12 \mathrm{~mm}$ $\mathrm{ZOI}$ at $20 \mu \mathrm{g} / \mathrm{disk}$, and a $10 \mathrm{~mm}$ bald ZOI at $2.5 \mu \mathrm{g} / \mathrm{disk}$. All other isolates were inactive. It is hypothesized that compounds which inhibit hyphae formation in Streptomyces $85 \mathrm{E}$ may block the proliferation of cancer. In the human breast cancer MCF-7 cells, proliferation can be blocked in numerous ways, including serum deprivation, pharmacological inhibition of specific kinase and steroid hormone pathways. ${ }^{23,24}$ Therefore, compound 2 was further evaluated for its cytotoxicity activity using several cancer cell lines. Compound $\mathbf{2}$ demonstrated a weak activity with the MCF-7 ( IC $_{50} 71.93 \mu \mathrm{mol} \mathrm{L}^{-1}$ or $\left.18 \mu \mathrm{g} \mathrm{mL}^{-1}\right), \mathrm{LNCaP}\left(\mathrm{IC}_{50} 77.92 \mu \mathrm{mol} \mathrm{L}^{-1}\right.$ or $\left.19.5 \mu \mathrm{g} \mathrm{mL}^{-1}\right)$, and LU-1 (147.85 $\mu \mathrm{mol} \mathrm{L} \mathrm{L}^{-1}$ or $\left.37.0 \mu \mathrm{g} \mathrm{mL}^{-1}\right)$, KB cells $\left(\mathrm{IC}_{50} 65.93 \mu \mathrm{mol} \mathrm{L} \mathrm{L}^{-1}\right.$ or $16.5 \mu \mathrm{g} \mathrm{mL}-1$ ), respectively.

Citrinin (2), a well-known mycotoxin, is both nephrotoxic ${ }^{13}$ and carcinogenic. ${ }^{25}$ It was reported to show moderate cytotoxicity against the mouse NS-1 cell line with $\mathrm{LD}_{99}$ values of $25 \mu \mathrm{g} \mathrm{mL}{ }^{-1},{ }^{15}$ and antifungal activities against Candida albicans, Cryptococcus neoformans, Aspergillus fumigatus, and A. niger at a concentration of $100 \mu \mathrm{g} /$ disk. ${ }^{14}$ It was documented too that penicitrone A (also known as dicitrinin A) (3) showed moderate cytotoxicity against the mouse NS-1 cell line with $\mathrm{LD}_{99}$ values of $6.3 \mu \mathrm{g} \mathrm{mL} \mathrm{m}^{-1},{ }^{15}$ and displayed scavenging activity with $\mathrm{IC}_{50}$ values of $55.3 \mathrm{mmol} \mathrm{L}^{-1}{ }^{16}$ while penicitrinol B (5) did not show cytotoxicity against P388, A-549, BEL-7402, and HL-60 cells $\left(\mathrm{IC}_{50}>50 \mu \mathrm{mol} \mathrm{L}-1\right) .{ }^{16}$

\section{Experimental}

\section{General procedures}

Optical rotations were measured using a JASCO P-1010 automatic polarimeter. UV spectra were measured on a HP 8453 UV-Visible spectrophotometer. FT-IR spectra were acquired on a Perkin-Elmer Spectrum BX spectrometer using $\mathrm{AgCl}$ film. Mass spectra and highresolution mass spectra were taken with a BioTOF II ESI mass spectrometer. 1D and 2D NMR spectra were recorded in $\mathrm{MeOH}-d_{4}$ and DMSO- $d_{6}$ on a Varian INOVA Unity $(500 \mathrm{MHz})$ spectrometer. The chemical shift 
( $\delta$ ) values are given in ppm with the residual $\mathrm{CD}_{3} \mathrm{OD}$ signals (3.31 ppm for ${ }^{1} \mathrm{H}$ and $49.15 \mathrm{ppm}$ for ${ }^{13} \mathrm{C}$ ) as internal standard, and the coupling constants $(J)$ are in Hz. Chromatographic fractions and pure compounds were monitored by TLC, detected by absorption of UV light at $254 \mathrm{~nm}$ and a color reaction by spraying with a solution of $10 \%, \mathrm{v} / \mathrm{v}$, sulfuric acid/EtOH followed by 5 min heating at $120^{\circ} \mathrm{C}$. MPLC (medium pressure column chromatography) was carried out on a Büchi ${ }^{\circledR}$ pump system and a Büchi column packed with Merck silica gel 60 and/or reversed-phase $\mathrm{C}_{18}$.

\section{Fungal material}

The fungal strain H9318 was isolated from the soil sample (MB 75) collected under an unidentified tree in a "Kerangas" or a heath forest at about 3000 feet (900 meters) above sea level located within the rim perimeter (south side) of Maliau Basin, Sabah, ${ }^{26}$ Malaysia in May 2001. The morphological characteristics of the Penicillium structure of H9318 as observed through light microscopic are circular conidia, the Ampulliforum philiades are shorter than the metula, 3 to 4 metulas were observed to branch from a single smooth stipe (of which some metulas were nonuniform in length). These characteristics points most likely to the subgenus Furcatum. ${ }^{27}$ The strain is maintained in the Laboratory Collection at the University of Malaysia Sabah. The isolation medium used was dichloran rose bengal chloramphenicol (DRBC) medium with $\mathrm{NaCl}(2.5 \%)$ at $\mathrm{pH}$ 5.6. Fungi were purified, and the producing strain was prepared on potato dextrose agar slants containing $\mathrm{NaCl} 10 \%, \mathrm{~m} / \mathrm{v}$, and stored at $4{ }^{\circ} \mathrm{C}$. Conidia of single colonies of microfungi were kept in anhydrous silica gel particles at $4{ }^{\circ} \mathrm{C}$. It was then ready to inoculate to a seed medium.

\section{Fermentation}

The composition of the seed and production medium (in $\mathrm{g} \mathrm{L}^{-1}$ ) was as follows: yeast extract (10), peptone (10), sucrose (10), $\mathrm{KH}_{2} \mathrm{PO}_{4}(1)$, and $\mathrm{MgSO}_{4} \cdot 7 \mathrm{H}_{2} \mathrm{O}(0.3)$. The seed medium was prepared with distilled water, and the $\mathrm{pH}$ was adjusted to 5.5 prior to sterilization. The medium was dispensed at $50 \mathrm{~mL}$ per $250 \mathrm{~mL}$ in Belco baffled shaker flasks. A single colony of Penicillium from the agar plate was used as inoculum into each flask of seed media, cultured at $30^{\circ} \mathrm{C}$ at $250 \mathrm{rpm}$ for two days. An aliquot (1.5\%) strain $\mathrm{H} 9318$ from the seed medium was inoculated into the production medium (similar composition) and were incubated at $30{ }^{\circ} \mathrm{C}$ at $220 \mathrm{rpm}$ for seven days and were then harvested.

\section{Extraction and isolation}

The microfungi fermentation culture $(90 \mathrm{~L})$ was centrifuged, and the supernatant was filtered and partitioned with $n-\mathrm{BuOH}$. Both the $n-\mathrm{BuOH}$-soluble and aqueous layers were tested against the hyphae formation inhibition (HFI) assay. The organic extracts were concentrated, suspended in $\mathrm{H}_{2} \mathrm{O}(1: 1, \mathrm{v} / \mathrm{v})$ and subsequently partitioned with hexane, $\mathrm{CHCl}_{3}$, and $\mathrm{EtOAc}(3 \times 500 \mathrm{~mL}$ each $)$. The $\mathrm{CHCl}_{3}$-soluble partition $(26.6 \mathrm{~g}$ ) of $n$ - $\mathrm{BuOH}$ extract of fermented Penicillium sp. H9318 significantly inhibited the growth of hyphae formation in Streptomyces $85 \mathrm{E}$ at a concentration of $80 \mu \mathrm{g} / \mathrm{disk}$, and was subjected to bioassayguided fractionation. This extract was chromatographed using silica gel $\mathrm{CC}$, eluting with a gradient of $\mathrm{CH}_{2} \mathrm{Cl}_{2}$ $\mathrm{MeOH}$, to afford ten fractions (H1-H10). Fraction H2 $(5.3 \mathrm{~g})$ was further separated on Sephadex LH-20 eluting with $\mathrm{CHCl}_{3}-\mathrm{MeOH}(1: 1, \mathrm{v} / \mathrm{v})$ to give one major fraction, which was crystallized from $\mathrm{CH}_{2} \mathrm{Cl}_{2}$ to afford the yellow crystalline compound 2 (2 g). Fraction H4 (100 mg, $\mathrm{CH}_{2} \mathrm{Cl}_{2}-\mathrm{MeOH}(50: 1$, v/v)) was chromatographed on silica gel and then Sephadex LH-20 $\left(\mathrm{CHCl}_{3}-\mathrm{MeOH}(1: 1\right.$, $\mathrm{v} / \mathrm{v})$ ), to afford compounds $\mathbf{3}(10.5 \mathrm{mg}), \mathbf{4}(5.6 \mathrm{mg})$, and $\mathbf{5}$ (7.0 mg). Fraction $\mathrm{H6}\left(80 \mathrm{mg}, \mathrm{CH}_{2} \mathrm{Cl}_{2}-\mathrm{MeOH}(30: 1, \mathrm{v} / \mathrm{v})\right)$ was separated further on Sephadex $\mathrm{LH}-20\left(\mathrm{CHCl}_{3}-\mathrm{MeOH}\right.$ $(1: 1, \mathrm{v} / \mathrm{v}))$ and then purified by reversed-phase $\mathrm{C}_{18}$ MPLC, eluting with $50 \% \mathrm{MeOH}$ to give compound $1(8.5 \mathrm{mg})$.

Isoquinocitrinin $A(1)$ : colorless oil; $[\alpha]_{\mathrm{D}}^{23}-5.2(c 0.42$, $\mathrm{MeOH}) ; \lambda_{\max } / \mathrm{nm}(\mathrm{MeOH})(\log \varepsilon): 207$ (4.15), 229 (sh, 3.78), 249 (sh, 3.66), 269 (3.54), 293 (3.58), 307 (3.59), 330 (sh, 3.53); IR ( $\mathrm{AgCl}$, film) $\mathrm{v}_{\max } / \mathrm{cm}^{-1} 3350,2928,1600,1508$, 1383, 1237, 1124, 1071, 910; ${ }^{1} \mathrm{H}$ and ${ }^{13} \mathrm{C}$ NMR see Table 1; LRESIMS $m / z 234\left(\mathrm{M}^{+}\right)$; LRESIMS $m / z 232\left(\mathrm{M}^{-}\right)$; HRESIMS $[\mathrm{M}+\mathrm{H}]^{+} \mathrm{m} / \mathrm{z}$ Found: 234.11248. Calc. for $\mathrm{C}_{13} \mathrm{H}_{16} \mathrm{NO}_{3}: 234.11247$.

\section{Hyphae formation inhibition assay}

The inhibition assay observed with hyphae formation in Streptomyces 85E was performed on purified isolates as described previously. ${ }^{4}$ The mycelia fragments of Streptomyces were spread on minimal medium ISP 4 agar plates for the generation of a bacteria lawn. Compounds of known concentration dissolved in $\mathrm{MeOH}$ were dispensed onto disks in $20 \mu \mathrm{L}$ aliquots. The impregnated paper disks (with a concentration of $80 \mu \mathrm{g} /$ disk) were applied directly on the surface of the agar plates seeded with Streptomyces $85 \mathrm{E}$. After $30 \mathrm{~h}$ of growth (during which the development of hyphae in Streptomyces species takes place), the results are identified by a clear zone of inhibition or bald phenotype around the disk. Surfactin, a sporulation inhibitor, and 
$\mathrm{MeOH}$ were employed as positive and negative controls, respectively. An inhibition zone of greater than $9 \mathrm{~mm}$ is considered active. Subfractions were tested at $80 \mu \mathrm{g} / \mathrm{disk}$ on $7 \mathrm{~mm}$ filter disks. Active compounds were tested at lower concentrations (20, 10, 5, $2.5 \mu \mathrm{g} / \mathrm{disk})$. The assays were performed in duplicate.

\section{Cytotoxicity assay}

The standard protocol for the assessment of cellular toxicity measures the ability of cultured cells to proliferate in the presence of test samples, and subsequently quantitates total protein content with sulforhodamine B dye as a measure of the percentage of surviving cells. ${ }^{28}$ The cytotoxic potential of citrinin was determined against the KB (human oral epidermoid carcinoma), LNCaP (androgen-sensitive human prostate adenocarcinoma), MCF-7 (human breast adenocarcinoma), and LU-1 (human lung carcinoma) cell lines. Cells were seeded in 96-well plates $\left(2-5 \times 10^{-4}\right.$ cells $\left.\mathrm{mL}^{-1}\right)$, and six two-fold serial dilutions of samples in $10 \%$ DMSO $(10 \mu \mathrm{L})$ were added to each well. The plates were incubated for $72 \mathrm{~h}$ at $37^{\circ} \mathrm{C}$, after which cell viability was determined with sulforhodamine $\mathrm{B}$ staining. $\mathrm{IC}_{50}$ values were determined as the concentration of sample required to inhibit cell growth by $50 \%$ relative to a control treated with $0.5 \%$ DMSO, and represent the average of triplicate values obtained from two independent experiments. $^{28}$

\section{Supplementary Information}

HRESIMS, ${ }^{1} \mathrm{H}$ and ${ }^{13} \mathrm{C}$ NMR spectra, HMQC, HMBC and NOESY spectra for compound $\mathbf{1}$ are available free of charge at http://jbcs.sbq.org.br as a PDF file.

\section{Acknowledgments}

We thank J. Davies for providing the strain of Streptomyces 85E; and B. Ostrowski (UMN-TC NMR Facility) for assistance with Varian Unity Inova $500 \mathrm{MHz}$ NMR measurements. Financial support from the American Chemical Society-Institutional Research Support, and the Research Council Seed grant, UH Hilo (L. C. C). This work was also supported by a grant in UMS (to H.C.C).

\section{References}

1. Persidis, A.; Nat. Biotechnol. 1998, 16, 1082.

2. Cohen, P.; Nat. Rev. Drug Discovery 2002, 1, 309.

3. Hong, S. K.; Matsumoto, A.; Horinouchi, S.; Beppu, T.; Mol.

Genet. Genomics 1993, 236, 347.
4. Waters, B. D.; Saxena, G.; Wanggui, Y.; Kau, D.; Wrigley, S.; Stokes, R.; Davies, J.; J. Antibiot. 2002, 55, 407.

5. Ong, S. M.; Voo, L. Y. C.; Lai, N. S.; Stark, M. J. R.; Ho, C. C.; J. Appl. Microbiol. 2007, 102, 680.

6. Xiang, W.; Chang, L. C.; Planta Med. 2006, 72, 735.

7. Shao, N.; Yao, G. M; Chang, L. C.; J. Nat. Prod. 2007, 70, 869.

8. Yao, G. M; Vidor, N. B.; Foss, A. P.; Chang, L. C.; J. Nat. Prod. 2007, 70, 901.

9. Yao, G. M; Chang, L. C.; Org. Lett. 2007, 9, 3037.

10. Yao, G. M; Kondratyuk, T. P.; Tan, G. T.; Pezzuto, J. M.; Chang, L. C.; J. Nat. Prod. 2009, 72, 319.

11. Marinho, A. M. R.; Rodrigues-Filho, E.; Moitinho, M. L.; Santos, L. S.; J. Braz. Chem. Soc. 2005, 16, 280.

12. Barber, J.; Cornford, J. L.; Howard, T. D; Sharples, D.; J. Chem. Soc., Perkin Trans. I 1987, 1, 2743.

13. Krogh, P.; Hasselager, E; Friis, P.; Acta Pathol. Microbiol. Scand., Sect. B: Microbiol. Immunol. 1970, 78, 401.

14. Clark, B. R.; Capon, R. J.; Lacey, E.; Tennant, S.; Gill, J. H.; Org. Biomol. Chem. 2006, 4, 1520.

15. Wakana, D.; Hosoe, T.; Itabashi, T.; Okada, K.; Campos Takaki, G. M.; Yaguchi, T.; Fukushima, K.; Kawai, K.; J. Nat. Med. 2006, 60, 279.

16. Lu, Z.-Y.; Lin, Z.-J.; Wang, W.-L.; Du, L.; Zhu, T.-J.; Fang, Y.-C.; Gu, Q.-Q.; Zhu, W.-M.; J. Nat. Prod. 2008, 71, 543.

17. Trisuwan, K.; Rukachaisirikul, V.; Sukpondma, Y.; Phongpaichit, S.; Preedanon, S.; Sakayaroj, J.; Tetrahedron 2010, 66, 4484.

18. Kohno, J.; Hiramatsu, H.; Nishio, M.; Sakurai, M.; Okuda, T.; Komatsubara, S.; Tetrahedron 1999, 55, 11247.

19. Hawas, U. W.; Shaaban, M.; Shaaban, K. A.; Speitling, M.; Maier, A.; Kelter, G.; Fiebig, H. H.; Meiners, M.; Helmke, E.; Laatsch, H.; J. Nat. Prod. 2009, 72, 2120.

20. Solecka, J.; Sitkowski, J.; Bocian, W.; Bednarek, E.; Kawecki, R.; Kozerski, L.; J. Antibiot. 2009, 62, 581.

21. Li, G.-Y.; Li, B.-G.; Yang, T.; Liu, G.-Y.; Zhang, G.-L.; Org. Lett. 2006, 8, 3613.

22. Rodig, O. R.; Ellis, L. C.; Glover, I.T.; Biochemistry 1966, 5, 2458.

23. Osborne, C. K.; Hobbs, K.; Clark, G. M.; Cancer Res. 1985, 45,584 .

24. Lobenhofer, E. K.; Huper, G.; Iglehart, J. D.; Marks, J. R.; Cell Growth Differ. 2000, 11, 99.

25. Ueno, Y.; Kubota, K.; Cancer Res. 1976, 36, 445.

26. Voo, C. L.; Lai, N. S.; Kibat, C.; Puah, S. H.; Hew, C. S.; Lee, K-H.; Ho, C. C.; J. Trop. Biol. Conserv. 2007, 3, 11.

27. Pitt, J. I.; The Genus Penicillium and its Teleomorphic States Eupenicillium and Talaromyces, Academic Press: London, 1979.

28. Skehan, P.; Storeng, R.; Scudiero, D.; Monks, A.; McMahon, J.; Vistica, D.; Warren, J.T.; Bokesch, H.; Kenney, S.; Boyd, M. R.; J. Natl. Cancer Inst. 1990, 82, 1107.

Submitted: May 20, 2010

Published online: February 22, 2011 


\section{Citrinin Derivatives from the Soil Filamentous Fungus Penicillium sp. H9318}

\section{Guangmin Yao, ${ }^{a, d}$ Fred Musoke Sebisubi, ${ }^{b, e}$ Lok Yung Christopher Voo, ${ }^{c}$ Coy Choke Ho, ${ }^{c}$ Ghee Teng Tan ${ }^{b}$ and Leng Chee Chang*,a,b}

${ }^{a}$ Department of Chemistry and Biochemistry, College of Science and Engineering,

University of Minnesota Duluth, 1039 University Drive, Duluth, MN 55812, USA

${ }^{b}$ Department of Pharmaceutical Sciences, College of Pharmacy, University of Hawaii Hilo, 34 Rainbow Drive, Hilo, HI 96720, USA

'Biotechnology Program, School of Science and Technology, University Malaysia Sabah, 88999 Kota Kinabalu, Sabah, Malaysia

${ }^{d}$ Hubei Key Laboratory of Natural Medicinal Chemistry and Resources Evaluation, School of Pharmacy, Tongji Medical College, Huazhong University of Science and Technology,

13 Hangkong Road, Wuhan 430030, P. R. China

${ }^{e}$ Division of Pharmaceutical Services, Ministry of Health,

PO Box 7272 Kampala, Uganda

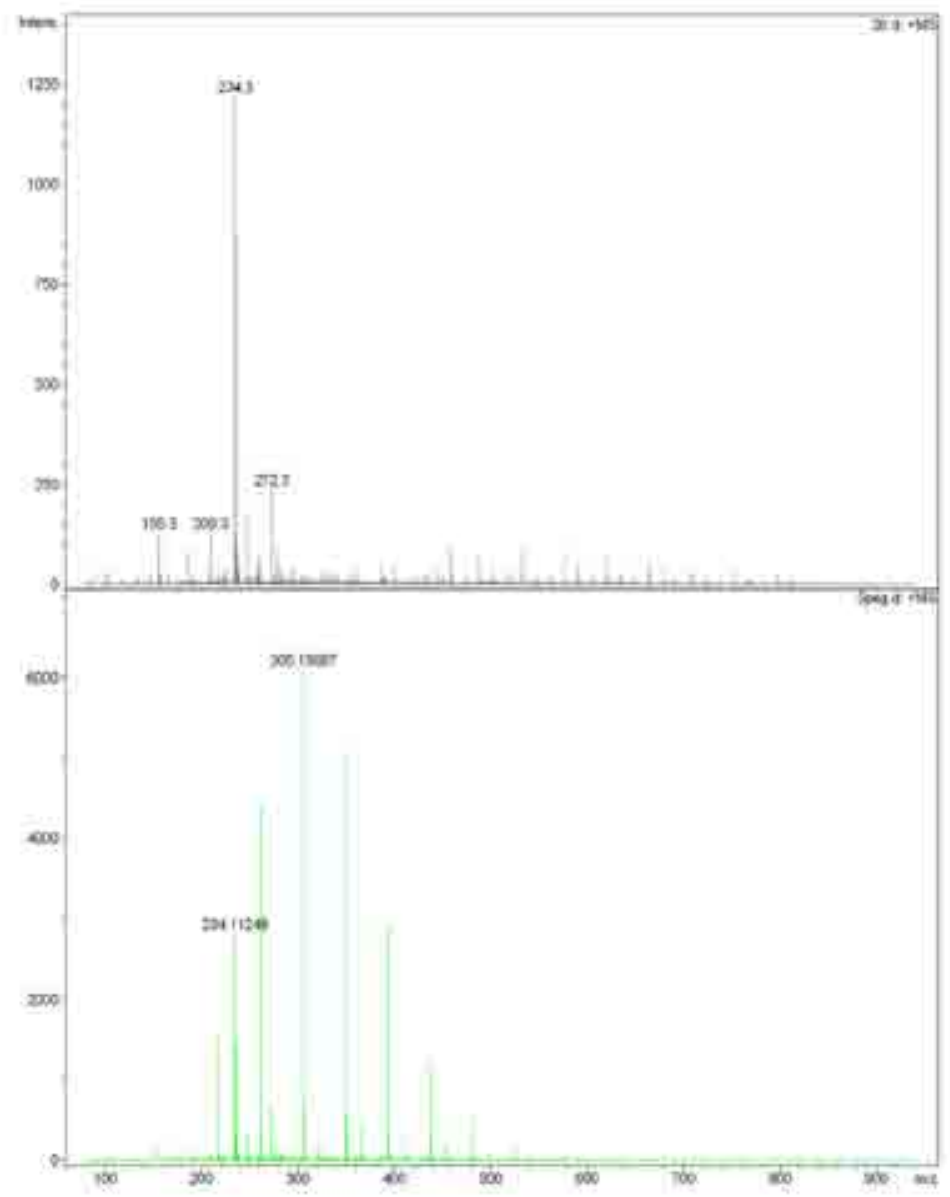

Figure S1. HR-(+)ESIMS spectrum of isoquinocitrinin A (1). 


\section{i}<smiles>CC1=C(O)c2cnc(C)c(C)c2C(O)(O)C1=O</smiles>

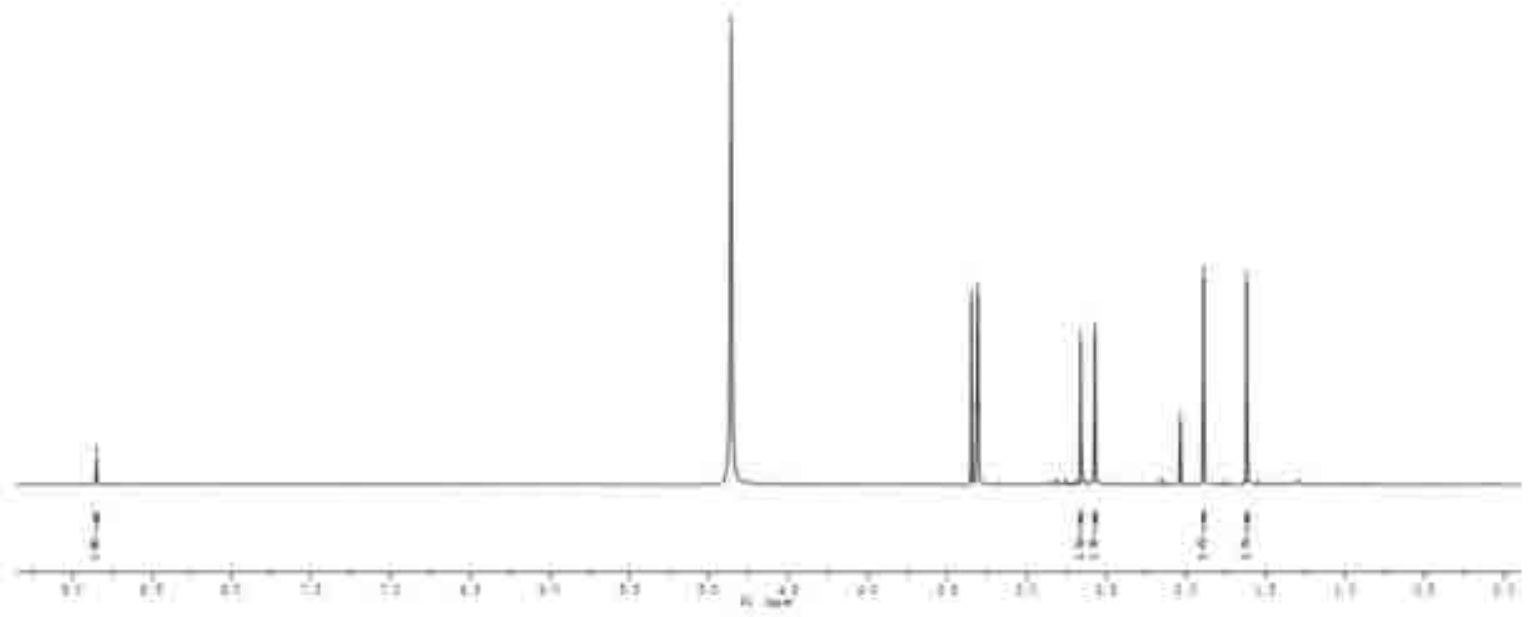

Figure S2. ${ }^{1} \mathrm{H}$ NMR spectrum of isoquinocitrinin $\mathrm{A}\left(1, \mathrm{CD}_{3} \mathrm{OD}, 500 \mathrm{MHz}\right)$.
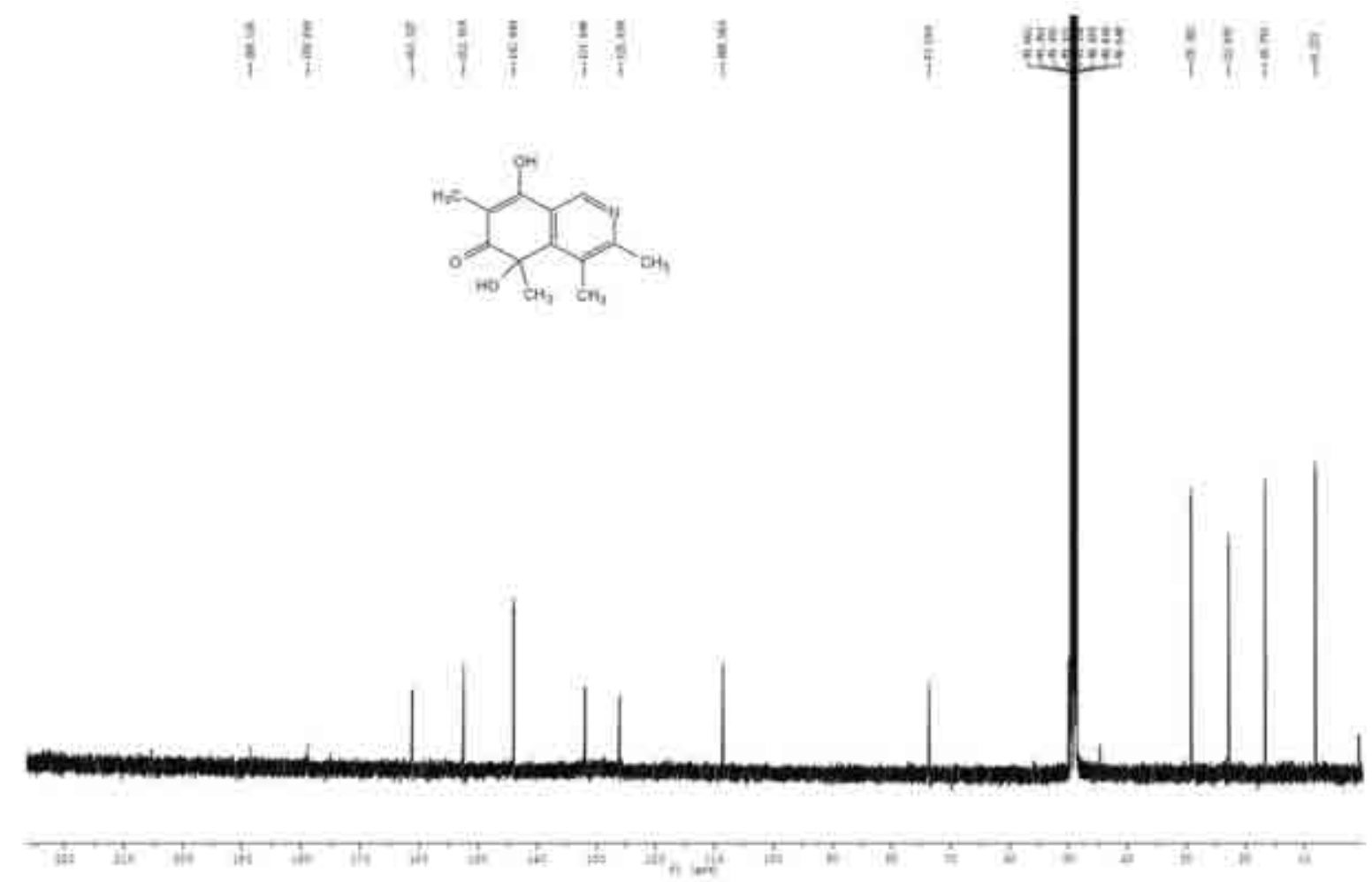

Figure S3. ${ }^{13} \mathrm{C}$ NMR spectrum of isoquinocitrinin $\mathrm{A}\left(\mathbf{1}, \mathrm{CD}_{3} \mathrm{OD}, 125 \mathrm{MHz}\right)$. 


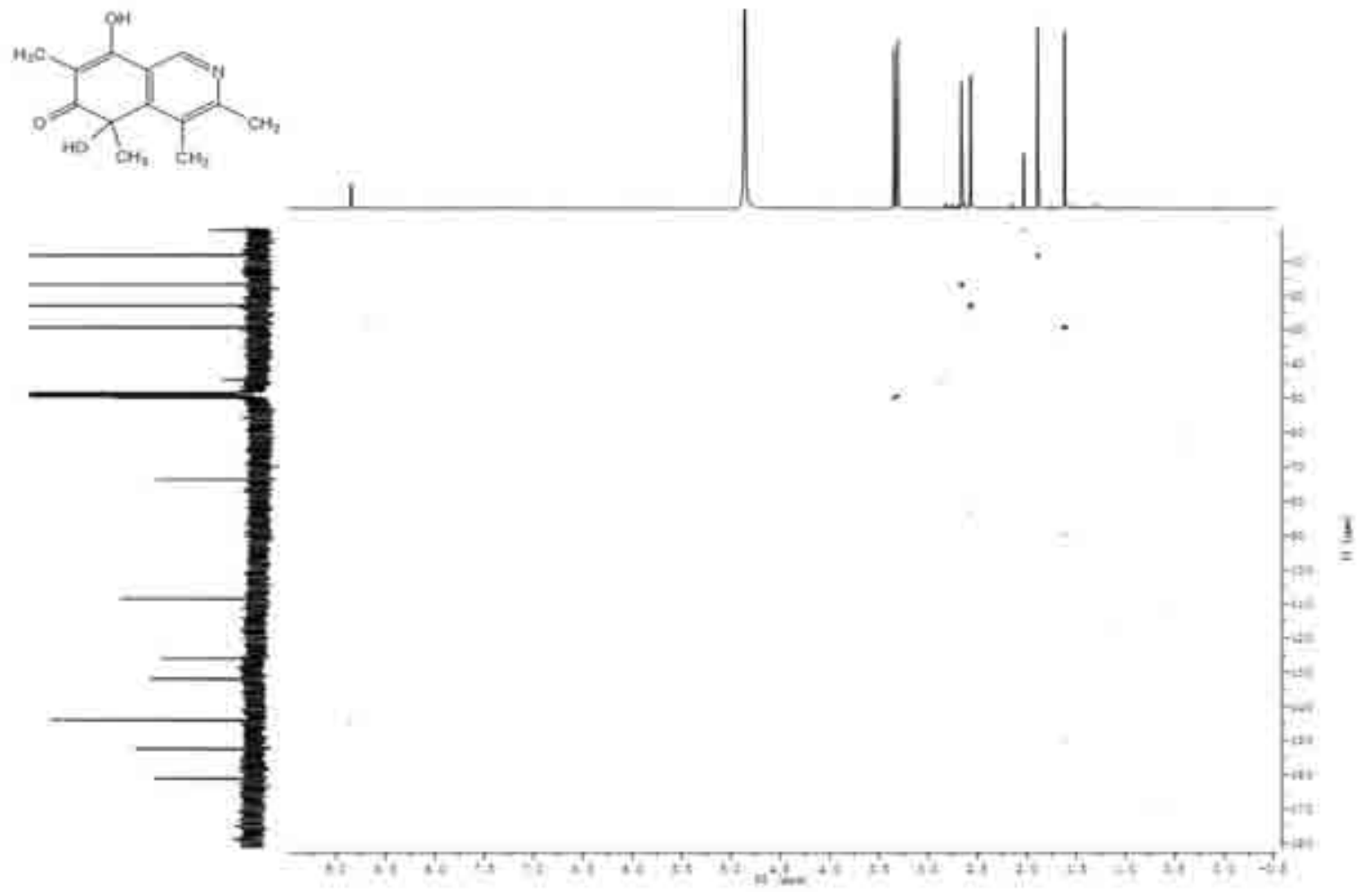

Figure S4. HMQC of isoquinocitrinin $\mathrm{A}\left(\mathbf{1}, \mathrm{CD}_{3} \mathrm{OD}\right)$.

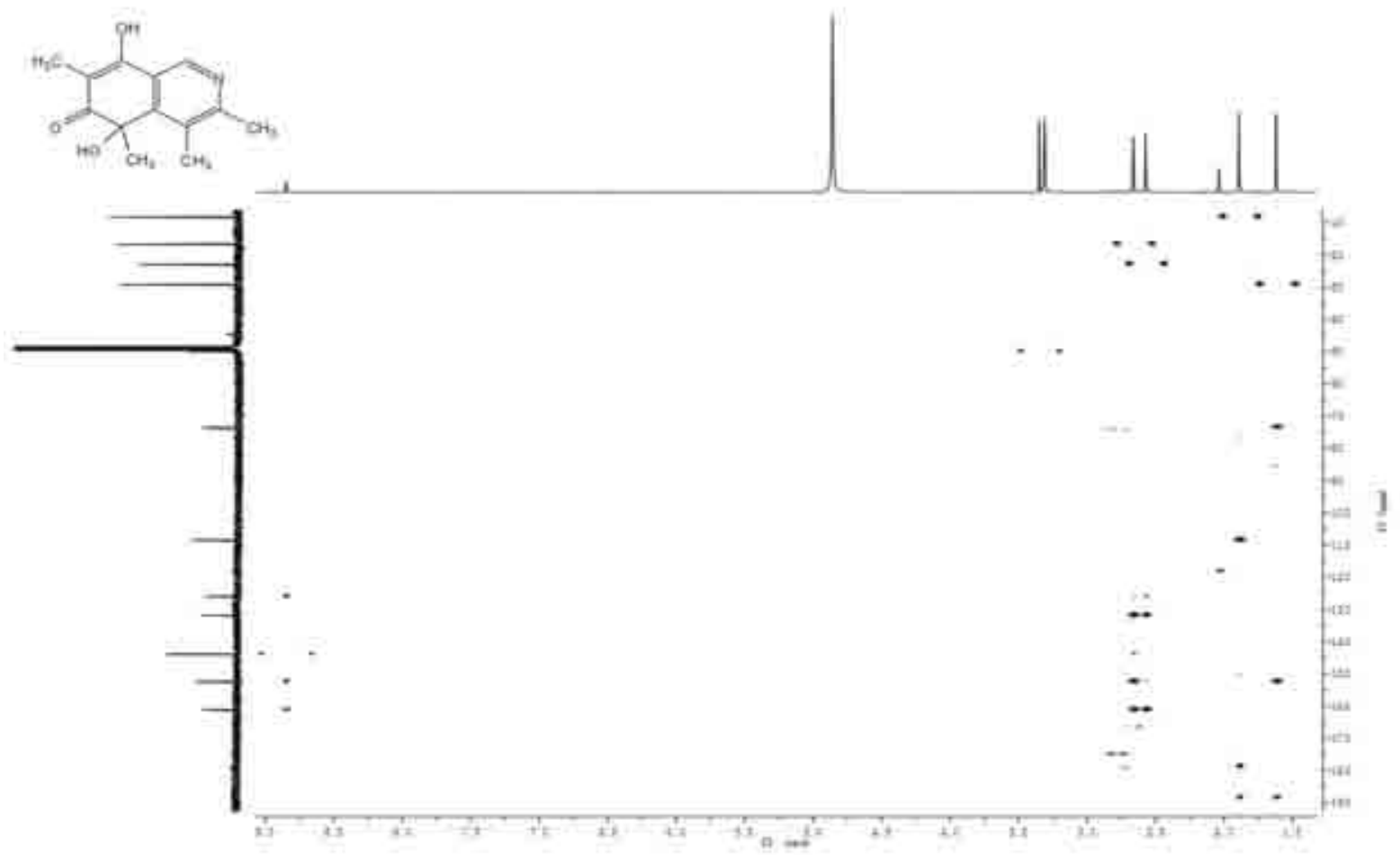

Figure S5. HMBC of isoquinocitrinin $\mathrm{A}\left(\mathbf{1}, \mathrm{CD}_{3} \mathrm{OD}\right)$. 


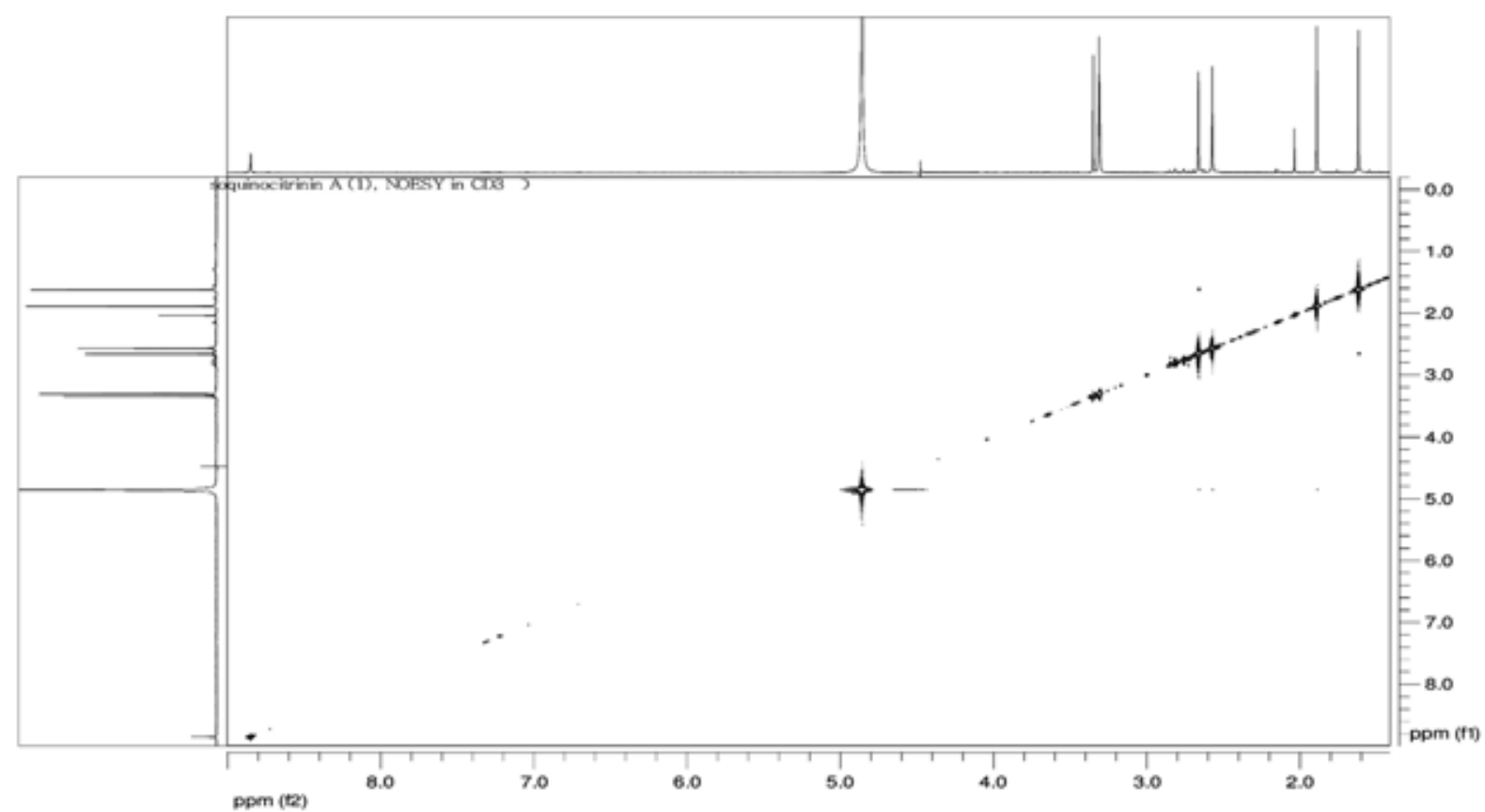

Figure S6. NOESY spectrum of isoquinocitrinin A (1, $\left.\mathrm{CD}_{3} \mathrm{OD}\right)$. 